\title{
ANALISIS HUKUM ISLÂM TERHADAP MASALAH KEKERASAN DALAM RUMAH TANGGA (KDRT)
}

\author{
Abd. Wahed
}

\begin{abstract}
A bstraks:
KDRT (domestic violence) must be ended. Both wife and husband come to a conclusion to finish it. However, it doesn't mean that the role of a husband, as discipline upholder, has to be denied. Islam does not agree with it. As an Imam (leader), a husband must maintain moral values to establish a peaceful and perfect harmonious family. UU. No 23 Th. 2004 implicitly states that domestic violence is any violence types occurring in a family. A husband has been a person who always be blamed on in this case. This artide analyzes a kind of violence committed by a husband against the family members--children and wife from the perspective of Fiqh (Islamic law)
\end{abstract}

\section{Kata kunci:}

KDRT, nusyûz, târik al-shalâh, dan hukum Islâm

\section{Pendahuluan}

Undang-Undang No. 23 Tahun 20041, tentang Penghapusan Kekerasan Dalam Rumah Tangga (selanjutnya disebut UU PKDRT) pasal 1 menyatakan bahwa tindakan Kekerasan Dalam Rumah Tangga (selanjutnya disebut KDRT) adalah “setiap perbuatan terhadap seseorang terutama perempuan, yang berakibat timbulnya kesengsaraan atau penderitaan secara fisik, seksual, psikologis, dan

1 Undang-undang N o. 23 Tahun 2004 tentang Penghapusan Kekerasan Dalam Rumah Tangga, (Jakarta: Cemerlang, t.t.h), hlm. 2. 
atau menelantarkan rumah tangga, termasuk ancaman untuk perbuatan, pemaksaan atau perampasan kemerdekaan secara melawan hukum dalam lingkup rumah tangga". Selanjutnya, pasal 2 UU PKDRT2 ${ }^{2}$ menyebutkan bahwa yang dimaksudkan dengan 'lingkup rumah tangga' adalah meliputi “suami, istri, dan anak; orang-orang yang mempunyai hubungan keluarga dengan (suami, istri dan anak) karena hubungan darah, perkawinan, persusuan, pengasuhan dan perwalian, yang menetap dalam rumah tangga; orang yang bekerja membantu rumah tangga dan menetap dalam rumah tangga tersebut".

Sementara itu, Islâm telah menggariskan bahwa laki-laki adalah 'penegak' bagi perempuan,3 yaitu dijadikan sebagai penanggung jawab terhadap berlangsungnya sebuah keluarga. Di antara tanggung jawab suami itu adalah 'memukul' istri apabila ia nusyûz dan memukul anaknya apabila ia târik al-shalâh (meninggalkan shalat), sedangkan anak tersebut sudah berusia sepuluh tahun. Di samping itu, suami memiliki kewajiban-kewajiban yang melekat kepada seorang suami sebagai tanggung jawab pribadinya kepada Allâh. Swt., seperti memberikan nafkah yang layak, melindungi keluarganya, dan lain-lain.

Tulisan ini akan membahas kategorisasi kekerasan dalam UU PKDRT, dan kategorisasi kekerasan yang harus dilakukan seorang suami sebagai pemimpin dalam suatu rumah tangga untuk menegakkan aturan-aturan Allâh swt. dalam rumah tangga tersebut. Sehingga pada akhirnya akan dapat ditarik benang merah di antara kedua hukum normatif dan formal tersebut.

Tinjauan atas Kekerasan dalam Rumah Tangga.

$2 \mathrm{lbid}, \mathrm{hlm} .3-4$

${ }^{3}$ Al-Qur'ân surat al-Nisâ' (4): 34. 
Kata kekerasan dalam bahasa Indonesia diartikan sebagai sifat (hal tertentu) keras, kegiatan kekerasan, paksaan, kekejangan. ${ }^{4}$ Istilah kekerasan dalam Kamus Besar Bahasa Indonesia diartikan sebagai 'perbuatan seseorang atau kelompok orang yang menyebabkan cedera atau matinya orang lain atau menyebabkan kerusakan fisik atau barang orang lain' ${ }^{5}$

Kata 'kekerasan' merupakan padanan kata 'violence' dalam bahasa Inggris, meskipun keduanya memiliki konsep yang berbeda. V iolence dalam bahasa Inggris diartikan sebagai suatu serangan atau invasi terhadap fisik maupun integritas mental psikologis seseorang. Sedangkan kata 'kekerasan' dalam bahasa Indonesia umumnya dipahami hanya menyangkut serangan secara fisik semata. ${ }^{6}$

Terlepas dari perbedaan pengertian etimologis, 'kekerasan' dan 'violence' tersebut, saat ini kekerasan tidak hanya diartikan secara fisik, namun juga psikis. Sebagaimana yang saat ini dikenal tentang kekerasan terhadap istri, anak, pembantu atau antar anggota keluarga dalam rumah tangga yakni, dapat berupa kekerasan fisik, kekerasan psikis, kekerasan seksual serta penelantaran rumah tangga sebagaimana diamanatkan oleh pasal 1 UU. No. 23 tahun 2004 tentang PKDRT.

Secara tegas, kekerasan dalam rumah tangga, diatur dalam pasal 5 UU PKDRT yang menyatakan bahwa "Setiap orang dilarang melakukan kekerasan dalam rumah tangga terhadap orang dalam ruang lingkup rumah tangganya, dengan cara: (a) kekerasan fisik; (b)

4 WJS. Purwodarminto, Kamus Besar Bahasa Indonesia, (Jakarta: Balai Pustaka, 1984), hlm.489.

5 Departemen Pendidikan dan Kebudayaan RI., Kamus Besar Bahasa Indonesia (Jakarta: PT. Gramedia, 1991), hlm. 513.

6Mansour Faqih, 'Perkosaan dan Kekerasan Analisis Gender', dalam Perempuan dal am Wacana Perkosaan, eds. Eko Prasetyo dan Suparman Marzuki (Yogyakarta: PKBI, 1997), hlm.7. 
kekerasan psikis; (c) kekerasan seksual, atau ; (d) penelantaran rumah tangga “. 7

Berdasarkan pasal tersebut, bentuk-bentuk kekerasan dalam rumah tangga dibagi menjadi kekerasan fisik (yaitu perbuatan yang mengakibatkan rasa sakit, jatuh sakit atau luka berat), kekerasan psikis (yaitu perbuatan yang mengakibatkan ketakutan, hilangnya rasa percaya diri, dan/ atau penderitaan psikis berat pada seseorang), kekerasan seksual (yaitu pemaksaan hubungan seksual yang dilakukan terhadap orang yang menetap dalam lingkungan rumah tangga tersebut, dan pemaksaan hubungan seksual terhadap seseorang dalam rumah tangga dengan orang lain untuk tujuan komersial dan/ atau tujuan tertentu), atau penelantaran rumah tangga (seperti orang yang mengakibatkan ketergantungan ekonomi dengan cara membatasi dan/ atau melarang untuk bekerja yang layak di dalam atau di luar rumah sehingga korban berada di bawah kendali orang tersebut). 8

Sebenarnya hal prinsip yang menjadi latar belakang diundangkannya UU No. 23 Th. 2004 ini adalah adanya kesadaran akan diskriminasi dan perlakuan tidak adil terhadap perempuan baik dalam ruang publik maupun dalam rumah tangga, serta adanya pelecehan terhadap anak dibawah umur dengan menjadi korban pelecehan seksual dan ekploitasi anak di bawah umur dan sebagainya. UU Ini merupakan ketentuan hukum yang mengatur tentang tindak kekerasan dalam rumah tangga, prosedur penanganan perkara, perlindungan terhadap korban dan sanksi bagi para pelakunya.

UU anti kekerasan dalam rumah tangga ini dilegislasikan dengan pertimbangan-pertimbangan sebagai berikut: Pertama, bahwa setiap warga berhak mendapatkan rasa aman dan bebas dari segala bentuk kekerasan suami. Kedua, bahwa segala bentuk kekerasan,

7 U ndang-undang N 0. 23 Tahun 2004, hlm.5

8 Pasal 6-9U ndang-undang N 0. 23 Tahun 2004, hlm. 5-6 
terutama kekerasan dalam rumah tangga, merupakan pelanggaran hak asasi manusia dan kejahatan terhadap martabat kemanusiaan serta bentuk diskriminasi yang harus dihapuskan. Ketiga, bahwa korban kekerasan dalam rumah tangga, yang kebanyakan perempuan dan anak-anak, harus mendapatkan perlindungan dari Negara dan atau masyarakat agar terhindar dan terbebas dari segala bentuk kekerasan atau ancaman kekerasan, penyiksaaan, atau perlakuan yang merendahkan derajat dan martabat kemanusiaan. Keempat, bahwa dalam kenyataannya kasus kekerasan dalam rumah tangga banyak terjadi, sedangkan sistem hukum Indonesia belum menjamin akan adanya perlindungan terhadap korban kekerasan dalam rumah tangga.

\section{Hak dan Kewajiban Suami Istri dalam Islâm.}

Konsep kehidupan keluarga dalam Islâm menempatkan semua anggota keluarga dalam porsi dan posisi yang sesuai dengan fitrah masing-masing. Suami sebagai kepala keluarga mempunyai hak yang lebih besar daripada istri sesuai dengan kewajibannya yang memang menempati posisi paling banyak. Demikian juga seorang istri mempunyai hak dan kewajiban yang sama sesuai dengan fitrahnya sebagai perempuan. Seorang anak juga mempunyai hak untuk disayang namun juga mempunyai kewajiban untuk menghormati orang tua.

Seorang pembantu rumah tangga mempunyai hak untuk mendapatkan upah yang layak, untuk mengerjakan pekerjaan sesuai dengan kemampuannya juga wajib mengikuti aturan yang ditetapkan oleh majikannnya selama tidak bertentangan dengan ajaran agama dan perundang-undangan yang berlaku. Juga berhak mendapat teguran apabila lalai terhadap tugasnya atau menyebabkan suatu kecelakaan kepada keluarga tersebut.

Proporsionalitas ini sebagaimana tergambar dari keumuman Hadîts muttafaq alayh riwayat ibn 'Umar berikut ini :

$$
\begin{aligned}
& \text { وعن ابن عمر رضي الله عنهما قال سمعت رسول الله صلى الله عليه وسلم يقول كلكم راع وكلكم } \\
& \text { مسئول عن رعيته والأمام راع ومسئول عن رعيته والرجل راع في أهله ومسئول عن رعيته والمرأة } \\
& \text { al-Ihkâm Vol.IV No.1 Juni } 2009
\end{aligned}
$$




$$
\text { وراعية في بيت زوجها ومسئولة عن رعيتها والخادم راع في مال سيده ومسئول عن رعيته فكلكم راع }
$$

“Dari Ibn 'U mar ra. Dia berkata: saya mendengar Rasûlullâh saw. Bersabda: setiap diri kalian adalah pemimpin dan akan diminta pertanggunganjawaban tentang kepemimpinannya, seoarang imam adalah pemimpin dan akan dimintai pertanggungjawaban tentang rakyatnya, seorang laki-laki adalah pemimpin dalam keluarganya dan akan dimintai pertanggungjawaban atas keluarganya, seorang perempuan adalah penjaga dalam rumah tangga suaminya dan akan dimintai pertanggungjawaban atas penjagaannya, dan seorang pembantu adalah penjaga terhadap harta tuannya dan akan dimintai pertanggungjawaban atas kepenjagaannya itu. Setiap kalian adalah pemimpin dan akan dimintai pertanggungjawaban atas kepemimpinannya itu."( HR. Bukhari-M uslim). ${ }^{9}$

Dari keumuman hadits tersebut, dapat dipahami bahwa setiap anggota keluarga mempunyai hak dan kewajiban serta tanggung jawab yang sama sesuai dengan porsi dan posisi masing-masing. Tidak dibenarkan apabila meminta perlakuan yang lebih melebihi hak dan kewajibannya tersebut.

Di antara hak seorang suami adalah mendapatkan penghormatan dan ketaatan secara layak dari anggota keluarga tersebut berkenaan dengan peran seorang kepala rumah tangga dan harus bertanggung jawab baik moral, material dan spiritual dalam menegakkan ajaran Allâh swt. Oleh karena itu kewajiban seorang suami meliputi hal-hal yang bersifat material duniawi dan spiritual ukhrâwî.

Kewajiban suami yang bersifat material di antaranya adalah memberikan nafkah yang layak menurut ukuran kemampuannya kepada anak, istri, dan anggota keluarga yang menjadi tanggungannya. Bukan layak menurut ukuran masyarakat di mana ia tinggal. Nafkah tersebut meliputi sandang papan dan pangan.

9 Abî Zakariyâ Muhy al-Dîn Yahya al-Nawâwî, Riyâdl al-Shâlihîn, (Surabaya: Darul Ulum, t.th.), hlm. 158. 
Kewajiban mental spiritualnya adalah memberikan bimbingan kepada istri dan anak serta anggota keluarga yang lain untuk selalu mentaati perintah Allâh swt. dan rasûl-Nya.

Termasuk kewajiban moral seorang suami adalah memberikan teguran bahkan hukuman yang layak dan bersifat mendidik bagi anggota keluarganya yang melanggar aturan Allâh swt. dan rasûlNya. la berkewajiban 'memukul' istrinya yang nusyûz dan anaknya yang târik al-shalâh setelah anak tersebut berumur sepuluh tahun dan ia telah melaksanakan kewajibannya mengajarkan shalât sejak anak tersebut berumur tujuh tahun.

Seorang istri berhak mendapatkan nafkah lahir dan bathin dari suami dan berhak mendapat perlindungan diri dan kehormatan dari suami, termasuk mendapatkan pendidikan yang sesuai dengan kemampuan suami apabila ia masih membutuhkan. Sedang kewajibannya adalah mentaati suami baik dengan kerelaan atau dengan keterpaksaan selama suaminya tersebut masih berdiri dalam koridor keridlaan Allâh swt. Dan seorang istri wajib menjadi asisten suami apabila si suami sedang tidak ada di rumah tempat tinggalnya.

\section{A nalisis H ukum Islâm terhadap KD RT}

Letak urgensi kajian ini adalah generalisasi kata "kekerasan" dalam rumah tangga, sehingga terkesan dalam rumah tangga tersebut tidak boleh terjadi kekerasan sama sekali walaupun kekerasan tersebut adalah bentuk pelaksanaan kewajiban penanggung jawab keluarga tersebut (baca: suami) dalam menjalankan kewajibannya demi untuk menjaga rel keluarga tersebut dalam garis keridlaan Allâh swt. Di sinilah dibutuhkan analisis yang mendalam tentang kekerasan dalam rumah tangga, apakah semua jenis kekerasan harus dihapuskan tanpa adanya garis tegas seorang suami boleh bersikap tegas dan menindak dengan keras terhadap pelanggaran-pelanggaran syar'î yang terjadi dalam rumah tangga tersebut sesuai dengan kewenangan atau kewajibannya.

Sementara hukum Islâm disyari'atkan bukan dengan hampa muatan, melainkan penuh dengan hikmah-hikmah disyari'atkannya suatu hukum. Di antara hikmah diperbolehkannya seorang suami 
Wahed

'memberi pelajaran' kepada istrinya adalah agar supaya semata-mata si istri tersebut selalu berada dalam kendali suami dalam rangka taat kepada Allâh swt. dan rasûl-Nya. Hal ini dimaksudkan untuk menghindari nusyûz dan gejala-gejala yang mengarah kepadanya. ${ }^{10}$

Hukum Islâm dalam menyikapi masalah KDRT ini lebih menitikberatkan kajiannya dalam masalah nusyûz di antara suami istri dan masalah târik al-shalâh anak yang berumur 10 tahun setelah diajari shalât oleh walinya sejak ia berumur tujuh tahun. Adapun tindakan keras dari suami terhadap pembantu misalnya karena tindakan sembrono dari pembantu tersebut belum didapatkan referensi untuk dianalisis secara hukum Islâm selama ia bukan merupakan pelanggaran kriminal yang dalam penanganannya diserahkan kepada pihak berwenang.

Berkaitan dengan nusyûz, al-Qur'ân surat al-Nisâ' (4) ayat 34 menyatakan :

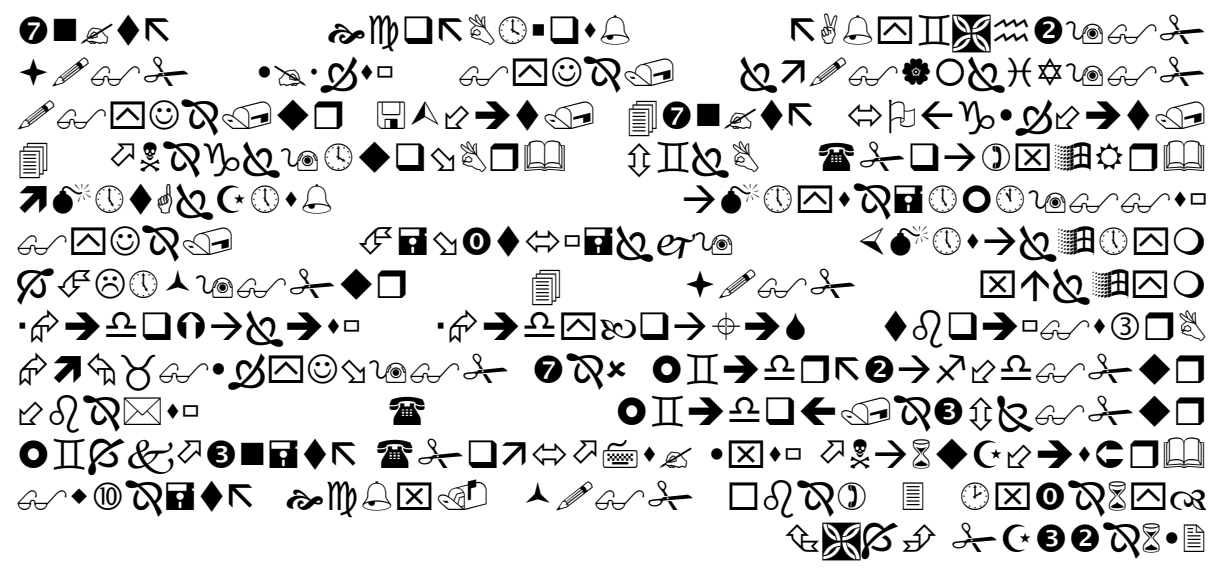

Artinya :

Laki-laki (suami) itu adalah pemimpin bagi kaum wanita, karena Allah telah melebihkan sebahagian mereka (laki-laki) atas sebahagian

10 Syaykh 'Alî A hhmad al-Jurjâwî, Hikmat al- Tasyrî' wa Falsafatuhu, Jilid 2 ( Kairo, Jâmi'ah al-A zhar, t.th), hlm.43. 
yang lain (wanita), dan karena mereka (laki-laki) telah menafkahkan sebagian dari harta mereka. sebab itu M aka wanita yang saleh, ialah yang taat kepada Allah dan memelihara diri ketika suaminya tidak ada, karena Allah telah memelihara (mereka). wanita-wanita yang kamu khawatirkan nusyûz, M aka nasehatilah mereka dan pisahkanlah mereka di tempat tidur mereka, dan pukullah mereka. kemudian jika mereka mentaatimu, M aka janganlah kamu mencari-cari jalan untuk menyusahkannya. Sesungguhnya Allah $M$ aha Tinggi lagi $M$ aha besar. ${ }^{11}$

Terkait dengan ayat tersebut, Tafsir Jalalain menerangkan bahwa para laki-laki adalah pemimpin yaitu yang menguasai para perempuan, memberikan pelajaran dan melindunginya, karena apa yang telah dilebihkan oleh Allâh swt. kepada sebagian mereka atas sebagian yang lain, seperti kelebihan dalam hal ilmu, akal dan perwalian, dan sebagainya, dan harta yang mereka nafkahkan. Selanjutnya, dijelaskan bahwa perempuan-perempuan yang shalih adalah yang taat kepada suaminya, menjaga diri dan kehormatannya ketika suaminya tidak ada, karena Allâh swt. telah menjaganya dengan cara mewasiatkannya kepada suaminya. Adapun bagi perempuan-perempuan yang dikhawatirkan akan berbuat nusyûz yaitu maksiat kepada suaminya dengan membangkang perintahperintahnya, maka nasehatilah mereka agar mereka takut kepada Allâh swt., dan pisahlah tempat tidur yakni pindahlah ke tempat tidur yang lain jika mereka masih berbuat nusyûz, dan pukullah mereka dengan pukulan yang tidak melukai jika dengan pisah tidur mereka belum kembali berbuat baik. Jika mereka telah kembali melakukan apa yang suami perintahkan, maka janganlah mencari cara untuk memukulnya untuk berbuat aniaya. 12

Melengkapi penjelasan di atas, al-Jurjâwî menegaskan bahwa kewajiban untuk memberikan pelajaran kepada istri adalah apabila ia mulai tidak taat dan menunjukkan gelaja nusyûz kepada suami. Maka

\footnotetext{
11 Departemen Agama RI. A I-Q ur'an dan Terjemahnya, (Surabaya: PT. Mahkota, 2004), hlm.108.

12 Jalâl al-Dîn al-Sayûthî, T afsîr Jalâlayn, Jilid 2 (Bandung: al-Ma'arif, t.th.), hlm. 86.
} 
si suami wajib memberikan pelajaran, akan tetapi pemberian pelajaran tersebut dilaksanakan dengan urutan bahwa pertama suami wajib memberikan peringatan kepada si istri dengan lembut dan halus seperti mengingatkannya untuk takut kepada Allâh swt., apabila si istri sudah taat kembali, maka cukup hanya sampai di situ. A pabila masih tetap membangkang, maka tinggalkan si istri itu sendirian, dengan meninggalkannya di tempat tidur, tidak mengumpulinya, lebih-lebih ketika syahwatnya memuncak. A pabila dia sudah taat, maka cukup sampai di situ dan kumpulilah istri tersebut seperti sediakala. Namun apabila tetap, maka si istri tersebut boleh 'dipukul' dengan catatan tidak terlalu keras dan tidak membuat cedera. ${ }^{13}$

Lebih lanjut beliau menjelaskan bahwa apabila dengan dipukul si istri tersebut masih membangkang juga, maka ia boleh dilaporkan kepada pihak yang berwenang, dalam hal ini ke pengadilan agama untuk menunjuk hakam atau juru damai di antara kedua belah pihak suami istri tersebut untuk mengharmoniskan hubungan keduanya.14 Menurut al-Jurjâwî, demikian hukum Allâh swt. yang telah digariskan dalam masalah nusyus ini.15

Dengan memahami analisis kedua ulamâ' di atas, dapat dipahami bahwa pemukulan suami terhadap istri yang nusyûz adalah lebih berupa kewajiban suami untuk mendidik istrinya agar selalu taat kepada Allâh swt., bukan merupakan tindakan kekerasan yang harus dihapuskan. Karena dengan demikian sunnatullâh dalam kehidupan berumah tangga sebagai suami istri yang diibaratkan bahtera di mana suami sebagai nakhkodanya dan si istri sebagai nâ'ibnya untuk membentuk keluarga yang sakînah, mawaddah warahmah akan tercapai. Berbeda halnya dengan kebebasan yang dipropagandakan oleh kalangan non muslim, di mana ia lebih

\footnotetext{
${ }^{13}$ Al-Jurjâwî, H ikmat al-Tasyrî,'hlm. 43.

${ }^{14}$ Al-Qur'ân Surat al-Nisâ (4): 35. A yat ini dikenal sebagai ayat syiqâq.

${ }^{15}$ Al-Jurjâwî, H ikmat al-Tasyrî,''hlm. 44
} 
bertujuan untuk menabrak sunnatullâh, tersebut sehingga masyarakat yang dibentuk adalah mayarakat yang bebas nilai dan berhaluan kebebasan yang sebebas-bebasnya.

Berkaitan dengan masalah 'pemukulan' seorang bapak atau ayah atau yang menjadi wâli al-shabi karena seorang anak yang tidak mau melaksanakan shalât padahal ia telah berumur sepuluh tahun dan sebelumnya sejak berumur tujuh tahun telah di ajarai shalât oleh walinya, maka hal ini dapat dianalisis melalui Hadîts Nabî sebagai berikut :

$$
\text { مروا أولادكم بمرو بن شعيب عن أبيه عن جده رضي الله عنه قال قال رسول الله صلى الله عليه وسلم أبناء سبع سنين واضربوهم عليها وهم أبناء عشر وفرقوا بينهم في حسن رواه أبو داود بإسناد حسن }
$$

D ari 'A mr ibn syua'yb dari bapaknya dari kakekknya, beliau bersabda: Bersabda Rasûlullâh saw. Perintahkan anak-anak kalian untuk mengerjakan shalât ketika sudah berumur tujuh tahun dan pukullah mereka apabila meninggalkan shalât ketika sudah berumur sepuluh tahun. D an pisahkanlah tempat tidur mereka (yang laki-laki dan perempuan).(HR. A bû Dâwud dengan sanad yang baik). 16

$$
\begin{aligned}
& \text { وعن أبي ثرية سبرة بن معبد الجهني رضي الله عنه قال قال رسول الله صلى الله عليه وسلم علموا }
\end{aligned}
$$

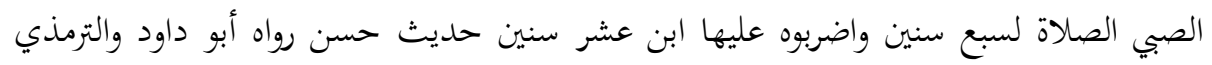

$$
\begin{aligned}
& \text { وقال حديث حسن ولفظ أبي داود مروا الصبي بالصلاة إذا بلغ سبع سنين }
\end{aligned}
$$

D ari A bî Tsurayyah Sibrah Ibn M a'bad al-Juhanî ra. Beliau bersabda: Bersabda Rasûlullâh saw.: Ajarkanlah seorang anak bersholat ketika ia berumur tujuh tahun dan pukullah mereka apabila meninggalkan sholat setelah berumur sepuluh tahun. HR. A bû Dâwud dan al-Tirmidzî. AlTirmidzî berkata, $\underline{H}$ adîts ini adalah $\underline{H}$ adîts hasan. A dapun redaksi A bû

16 al-Nawâwî, Riyâdl alShâlihîn, hlm. 158 
Wahed

Dâwud adalah: Perintahkanlah seorang anak dengan shalât ketika ia berumur tujuh tahun. ${ }^{17}$

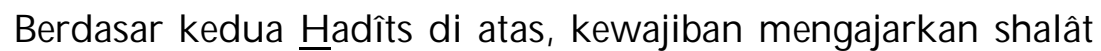
kepada anak-anak kaum Muslim dibebankan kepada kedua orang tuanya dimulai sejak anak tersebut berumur tujuh tahun dan dipantau dalam pelaksanaan shalât tersebut sehingga apabila ia telah berumur sepuluh tahun, maka apabila si anak tersebut lalai untuk mengerjakan shalât maka orang tuanya, dalam hal ini bapaknya wajib memberikan pelajaran kepadanya dengan 'memukul' yang tidak keras dan tidak menimbulkan bekas, yang dimaksudkan supaya ia lebih memperhatikan dalam melaksanakan shalât. Kewajiban memukul ini dimaksudkan sebagai sarana pendidikan dan tahdzir (menakut-nakuti) agar si anak itu apabila sampai masanya nanti 'aqil baligh tidak menjadi orang yang târik al-shalâh. Dimana derajat seorang yang meninggalkan shalât lebih hina dari anjing dalam pandangan syarî'ah. Jadi pada intinya perintah ini adalah untuk berhati-hati agar sesuatu yang tidak dikehendaki (meninggalkan shalât) terjadi apabila telah jatuh taklif (perintah mengerjakan syarî'ah) kepada anak tersebut.

Kedua teks yang memerintahkan untuk memukul, baik pada kasus istri yang nusyûz atau anak yang târik al-shalâh padahal ia masih berumur sepuluh tahun adalah teks-teks yang sharih petunjuknya dan dapat dikatagorikan sebagai nash yang qath'î al-dalâlah. Sehingga petunjuk hukum teks tersebut tidak boleh diinterfensi ulang, melainkan harus dilaksanakan sebagaimana petunjuknya. Karena dengan sendirinya teks tersebut bukan merupakan lapangan aplikasi ijtihâd. Akan tetapi bentuk-bentuk pemukulan itu yang masuk ke dalam lapangan ijtihâd. Karena kata fadlribû dalam kedua teks tadi adalah berupa kata umum, sehingga dibutuhkan ta'wîl (penjelasan) agar tidak disalahfahami dalam pelaksanaannnya nanti.

Berkenaan dengan bentuk pemukulan dalam kasus nusyûz terdapat sebuah $\underline{\mathrm{H}}$ adîts yang diriwayatkan oleh al-Turmudzî ra.:

17 Ibid., hlm. 159 


$$
\begin{aligned}
& \text { عن عمرو ابن الاحوص انه سمع رسول الله صلى الله عليه وسلم يقول : ... الى ان قال : فإن } \\
& \text { فعلن فاهجروهن في المضاجع واضربوهن ضربا غير مبرح فإن اطعنكم فلا تجعلوا عليهن سبيلا }
\end{aligned}
$$

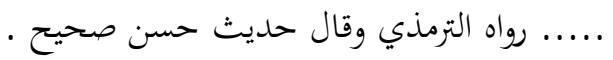

Dari 'Amr ibn al- Ahwash, ia mendengar Rasûlullâh saw., bersabda... : A pabila ia (istri) tersebut nusyûs maka tinggal kanlah di tempat tidur dan pukullah dengan pukulan yang tidak melukai, apabila ia sudah taat kepada kalian, maka janganlah kalian mencari jalan untuk aniaya kepadanya. (HR.al-Turmudzî).18

Dengan takhshîs dari hadits ini, maka jelaslah bahwa pukulan yang diperbolehkan dalam kasus nusyûz ini adalah pukulan yang tidak sampai menyebabkan luka dan apalagi cidera. Berbeda halnya halnya dengan pukulan yang harus dilaksanakan terhadap anak yang berumur sepuluh tahun yang meninggalkan shalât, maka jelas-jelas hanya pukulan yang bersifat mendidik dan menakut-nakuti saja, karena pada usia ini apabila ia belum baligh ia belum dikenai taklif. Sehingga pada masa baligh-nya nanti ia menjadi orang yang sangat perhatian terhadap shalât berkat kebiasaan yang ditanamkan sejak ia baru tamyîz.

Adapun bentuk-bentuk kekerasan lain yang mungkin terjadi dalam sebuah keluarga adalah di luar lingkup analisis ini. Untuk itu diperlukan adanya kajian mendalam terhadap UU PKDRT setelah mengecualikan kedua bentuk 'kekerasan/ pemukuan' tadi. Hal ini perlu ditegaskan kembali agar tidak terjadi kontra produktif antara UU PKDRT tersebut dengan pasal 29 ayat 2 Batang Tubuh UUD 1945, di mana setiap warga negara dijamin kebebasannya dalam menjalankan ajaran agamanya.19 Menurut hemat penulis, ketegasan seorang suami dalam menindak istrinya yang nusyûz dan anaknya yang târik al-shalâh adalah salah satu dari bentuk kebebasan

\footnotetext{
18 al-Nawâwî, Riyâdl al-Shâlihîn, hlm. 150.

19 UUD 1945 Pasal 2 ayat 1. Lihat Undang-U ndang Dasar RI. 1945, yang Sudah D iamandemen, (Surabaya: A pollo, t.th.), hlm. 21.
} 
Wahed

menjalankan ajaran agama yang dijamin oleh pasal 29 ayat 1 Batang Tubuh UUD. 1945.

\section{Reinterpretasi Fiqh tentang KD RT}

Salah satu ayat al-Qur'ân yang sering dianggap tidak membela kaum perempuan adalah ayat ke-34 surat al-Nisâ', yang menyatakan bahwa laki-laki adalah pemimpin dari perempuan, dan melegalkan pemukulan suami ketika istri berbuat nusyûz. Ayat ini sering dijadikan alasan yang mendukung budaya patriarkhi, yaitu bahwa laki-laki adalah pemimpin bagi perempuan baik dalam masyarakat secara umum maupun dalam rumah tangga.

Dalam tafsir al-M îzan, dinyatakan bahwa kata rijâl dan nisâ' dalam ayat tersebut tidak bersifat umum yaitu laki-laki dan perempuan. Akan tetapi laki-laki dan perempuan dalam hubungannnya dalam rumah tangga, yaitu suami istri. Karena dalam ayat tersebut juga dipaparkan tentang perempuan-perempuan yang shâlihah yang menjaga diri ketika suaminya tidak ada, dan seterusnya, serta tindakan laki-laki ketika perempuan berbuat nusyûz, maka laki-laki dan perempuan dalam konteks ini adalah suami dan istri dalam rumah tangganya. 20

Senada dengan pendapat di atas, Asghar Ali Engineer juga menyatakan bahwa konteks ayat tersebut dibatasi hanya dalam rumah tangga. Menurutnya, secara normatif, memang al-Qur'ân menempatkan laki-laki dalam kedudukan yang lebih superior terhadap perempuan. Namun, al-Qur'ân tidak menganggap atau menyatakan bahwa struktur sosial bersifat normatif. Sebuah struktur sosial tidak pasti dan memang selalu berubah, dan jika pada sebuah struktur sosial dimana perempuan yang menghidupi keluarganya, atau menjadi teman kerja laki-laki, maka perempuan pasti sejajar atau bahkan superior terhadap laki-laki dan memainkan peranan yang 20 Sayyid M uhammad 브usayn al-Tabatha'i, A I-M îzan fî al-Tafsîr, (Lebanon: al-'Alamî,
t.th.), IV: 343-346. 
dominan di dalam keluarganya sebagaimana yang diperankan lakilaki.21

Adapun tentang diperbolehkannya pemukulan dalam ayat tersebut, dapat dipahami berdasarkan peristiwa khusus yang menyebabkan turunnya (asbâb al-nuzul) ayat tersebut. Ayat tersebut turun setelah ada seorang laki-laki yang melukai istrinya. Kemudian saudara si istri tersebut mengadukannya kepada Rasûlullâh saw., sehingga beliau memerintahkan untuk dilakukan qishash. Dalam riwayat Ibnu Murdawayh disebutkan bahwa seorang sahabat anshâr menempeleng istrinya sampai berbekas. Kemudian si istri tersebut mengadukan kepada Rasûlullâh, dan beliau melarang berbuat demikian. Kemudian turunlah ayat 34 surat al-Nisa' ini.22

Berdasar asbâb al-nuzul di atas, dapat dipahami bahwa ayat tersebut dalam konteks rumah tangga, dan pemukulan diperbolehkan pada saat itu untuk membatalkan keputusan Rasûlullâh saw. tentang qishash. Namun demikian, pemukulan dalam hal ini hendaknya dimaknai untuk memberikan pelajaran, bukan untuk menyakiti isteri.

Berkaitan dengan pemukulan terhadap isteri, terdapat $\underline{H}$ adîts Nabî yang diriwayatkan oleh Imâm Muslim dalam kitab Shahîh-nya, di antara khutbah Nabî pada haji wada', sebagai berikut:

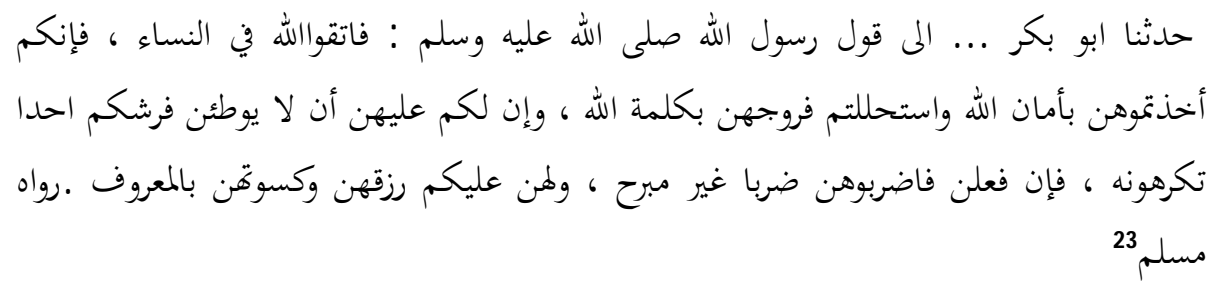

21 Asghar Ali Engineer, Islam dan Teologi Pembebasan, terj. Agung Prihantoro, (Yogyakarta: Pustaka Pelajar, 1999), hlm. 237.

22 A bû Bakr al-Sayûthî, Lubab al-N uqul fî A sbâb al-N uzul (Hamisy Tafsîr Jalâlayn), jilid 1 (Bandung: Al-Ma'arif, t.t), hlm. 92.

${ }^{23}$ A bû al-Hasan Muslim Ibn al Hajjaj al-N aysaburî, Shahîh M uslim, Jilid IV (Kairo: Dâr

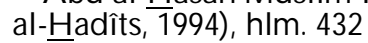


M enceritakan kepada kami A bû Bakar...dst. sampai sabda Rasûlulâh saw.: "Takutlah kalian kepada Allâh terhadap perempuan karena kamu sekalian telah mengambil mereka sebagai amanah Allâh dan dihalalkan bagimu kehormatannya (menggaulinya) dengan kalimah Allâh, dan bagimu agar istri-istrimu tidak melakukan jimak dengan laki-laki lain yang tidak mau sukai di ranjangmu, maka pukullah istri-istrimu itu dengan pukulan yang tidak menyebabkan luka, dan istri-istrmu berhak atas rizki dan pakaian yang baik".

Berdasarkan Hadîts di atas, dapat dipahami bahwa pemukulan diperbolehkan karena istri berbuat zinâ yang keji. Dalam tafsir al-M îzan juga dijelaskan, berkaitan dengan penjelasan ayat 19 surat al-Nisa' tentang larangan untuk menguasai yaitu menahan, mempersempit gerak langkah dan mengekang. Larangan tersebut diberi pengecualian yaitu jika mereka berbuat fahisyah mubayyanah. Kata fahisyah dalam al-Qur'ân biasanya digunakan untuk menyebut perbuatan zinâ, sementara mubayyanah dari kata bayyana cenderung mempunyai arti pembuktian, sehingga perbuatan keji yang dimaksud adalah perbuatan zinâ yang terbukti. ${ }^{24}$

Dengan melihat dlahir hadits ini, nusyûz harus dipahami sebagai suatu fenomena pembangkangan istri terhadap suami secara lebih luar biasa sehingga berani berhubungan dengan lawan jenis di ranjang suaminya. Maka dengan demikian hubungan antara konteks pemukulan dengan nusyûz menurut pemahaman klasik perlu diinterpretasi kembali dan dirumuskan kembali dalam kajian figh. Sehingga hukum Islâm tidak kaku dan lentur mengarahkan umatnya harmonis mengikuti gerak zaman.

Terdapat sedikit perbedaan persepsi antara nusyûz klasik dan komtemporer. Akan tetapi hakikatnya adalah sama, yaitu pembangkangan istri terhadap suami dalam hal-hal yang diperbolehkan atau dianjurkan syara'. Namun demikian keumuman ibarah dalam ayat tentang nusyûz merupakan jawaban atas permasalahan ini baik yang dahulu atau yang sekarang. Karena

24Al-Tabatha'i, Al-M îzan, hlm. 254-255 
sebagaimana diketahui, ibarah yang berlaku dalam al-Qur'ân adalah berdasar petunjuk keumumannya, bukan karena sebab yang melatarbelakangi turunnya ayat al-Qur'ân tersebut. AI-Shabunî dalam kitab al-Tibyân menyatakan bahwa ulamâ' ushûl berbeda pendapat mengenai hal ini. Beliau menyatakan:

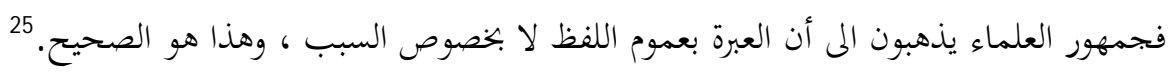

M ayoritas ulama' ushul memahami bahwa 'ibarah yang diambil dari teks-teks al-Qur'ân adalah dengan keumumam lafadznya, bukan dengan kekhususan sebab turunnya ayat tersebut. Ini pendapat yang shahih.

Walaupun tindak pemukulan dibenarkan dalam Islâm, ketika isteri berbuat nusyûz, namun pemukulan ini bukan berarti tindak kekerasan, karena tujuan dari pemukulan ini bukanlah untuk menyakiti, melainkan untuk memberi pelajaran. Jadi dengan demikian harus dijelaskan bedanya dengan kekerasan yang menjadi bahasan dalam UU KDRT di atas.

Berbeda halnya dengan pemukulan yang sampai mengakibatkan luka atau cedera, maka dapat dianggap sebagai kekerasan suami terhadap istri dan kepadanya dapat diaplikasikan hukuman yang diamanatkan oleh UU. PKDRT. Karena, walaupun misalnya pemukulan tersebut adalah tindakan suami karena isrtinya nusyûz, akan tetapi karena telah melewati batas yang diperbolehkan dalam Islâm maka bisa dianggap sebagai sebuah 'kekerasan'.

Di samping ayat tentang nusyûz ini, banyak terdapat ayat yang lain memerintahkan untuk mempergauli istri dengan ma'rûf dan larangan menyakiti isteri atau larangan untuk berbuat kemodlaratan terhadap isteri. Yang dimaksud dengan ma'rûf adalah sesuatu yang diketahui dalam masyarakat mengandung kebaikan, tidak ada yang tidak mengetahuinya atau menyangkalnya. Seperti budi pekerti yang baik, akhlakul karimah dalam bergaul dengan keluarga, dan dalam

\footnotetext{
25 Muhammad ‘Alî al-Shabûnî, A I-Tibyân fî 'U lûm al-Q ur'ân, (Jakarta: Dinamika Berkat Utamā, 1985), hlm. 29.
} 
masyarakat. Telah dijelaskan dalam al-Qur'ân pula bahwa semua manusia (baik laki-laki maupun perempuan) merupakan kesatuan kemanusiaan yang berasal dari asal yang satu. Mereka saling mebutuhkan dan membentuk masyarakat. Masing-masing mempunyai kekhususan, seperti laki-laki bersifat kuat dan tegas, sedangkan perempuan bersifat lembut dan penuh kasih. Akan tetapi masing-masing saling membutuhkan. ${ }^{26}$

Sedangkan anak-anak sebagai objek pendidikan yang paling muda dalam sebuah rumah tangga harus diperlakukan dengan lembut sesuai karakter mereka sebagai anak-anak. Banyak Hadîts yang menganjurkan hal demikian. Akan tetapi berbeda ketika anakanak tersebut akan lalai dalam mengerjakan shalât, maka perintah untuk mengingatkan mereka dan mendidik mereka lebih keras dan lebih ditegaskan ketimbang perintah yang lain. Hal ini mengingat pentingnya shalât dalam membentuk kepribadian seorang Muslim.

\section{Penutup}

Konsep nusyûz dalam hukum Islâm tidaklah melegalkan kekerasan terhadap isteri. Pemukulan terhadap istri yang berbuat nusyûz yang termuat dalam Q.S. surat al-Nisâ' (4): 34, hendaknya dimaknai sebagai tindakan untuk memberi pelajaran, bukan untuk menyakiti bahkan berbuat kekerasan, karena pemukulan tersebut tidak boleh melukai. Demikian juga halnya pemukulan terhadap anak yang telah berumur sepuluh tahun yang masih meninggalkan shalât seyogyanya dimaknai sebagai sarana mendidik anak tersebut untuk menjadi orang yang shâlih. Semua ini adalah bentuk tanggung jawab seorang suami/ayah sebagai kepala keluarga untuk mengikuti perintah Allâh swt. agar selalu menjaga diri keluarga dari api neraka.

Melalui analisis di atas, dapat ditarik benang merah bahwa sesungguhnya suami atau ayah berada di antara tuntutan untuk melaksanakan perintah agama 'berusaha menghindarkan diri dan keluarga dari api neraka' sebagai hukum normatif seorang Muslim

26 al-Tabatha'i, A I-M îzan, hlm 256. 
dengan ketaatannya mengikuti anjuran UU PKDRT sebagai hukum formatif baginya untuk 'menghidari kekerasan agar tidak terjadi dalam keluarganya'.

\section{D aftar Pustaka:}

Departemen Agama RI. Al-Qur'an dan Terjemahnya. Surabaya: PT. Mahkota, 2004.

Departemen Pendidikan dan Kebudayaan RI., Kamus Besar Bahasa Indonesia. Jakarta: PT. Gramedia, 1991.

Engineer, Asghar Ali. Islam dan Teologi Pembebasan, terj. Agung Prihantoro. Yogyakarta: Pustaka Pelajar, 1999.

Faqih, Mansour. 'Perkosaan dan Kekerasan Analisis Gender', dalam Perempuan dalam Wacana Perkosaan, eds. Eko Prasetyo dan Suparman Marzuki. Yogyakarta: PKBI, 1997.

Jurjâwî, Syaykh 'Alî A himad al-. H ikmat al- Tasyrî' wa Falsafatuhu, Jilid 2. Kairo, Jâmi'ah al-Azhar, t.th.

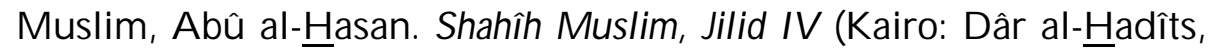
1994.

Nawâwî, Abî Zakariyâ Muhy al-Dîn Yahya al-. Riyâdl al-Shâlihîn. Surabaya: Darul Ulum, t.th.

Purwodarminto, WJS. Kamus U mum Bahasa Indonesia. Jakarta: Balai Pustaka, 1984.

Sayûthî, A bû Bakr al-. Lubâb al-N uqul fî A sbâb al-N uzul (H amisy Tafsîr Jalâlayn), jilid 1. Bandung: Al-Ma'arif, t.th.

Sayûthî, Jalâl al-Dîn al-. Tafsîr Jalâlayn, Jilid 2. Bandung: al-Ma'arif, t.th. 
Wahed

Shabûnî, Muhammad 'Alî al-. Al-Tibyân fî 'Ulûm al-Qur'ân. Jakarta: Dinamika Berkat Utama, 1985.

Tabatha'i, Sayyid Muhammad ㅂusayn al-. Al-M îzan fî al-Tafsîr. Lebanon: al-'Alamî, t.th.

U ndang-U ndang Dasar RI. 1945, yang Sudah Diamandemen. Surabaya: Apollo, t.th..

Undang-undang No. 23 Tahun 2004 tentang Penghapusan Kekerasan D alam Rumah Tangga. Jakarta: Cemerlang, t.t.h. 